\title{
Gills Scanning Images of the Seawater Fish Eugerres brasilianus (Gerreidae)
}

\author{
Daura Regina Eiras-Stofella ${ }^{{ }^{*}}$ and Patricia Charvet-Almeida ${ }^{2}$ \\ ${ }^{1}$ Centro de Microscopia Eletrônica, Universidade Federal do Paraná, Caixa Postal 19031, CEP 81530-900, \\ Curitiba-PR, Brazil; ${ }^{2}$ Departamento de Zoologia, Museu Paraense Emílio Goeldi, Av. Perimetral 1901,CEP 66077- \\ 530, Belém-Pará, Brazil
}

\begin{abstract}
The gills of the adult fish, Eugerres brasilianus (Gerreidae) were analyzed in a scanning electron microscope. The stratified epithelium was uniform on all parts of the branchial arch. Concentric microridges were present on cells that form this epithelium and were mainly observed in the primary lamellae and pharyngeal region where mucous cells were also abundant. The ultrastructural features of E. brasilianus gills indicated that this was not a filtering species, and that the feeding habit included mainly the intake of small organisms. The results presently obtained agreed with other literature data which determined the feeding habit of this species by means of stomach content analysis and other aspects..
\end{abstract}

Key words: Gill, morphology, scanning, Eugerres brasilianus

\section{INTRODUCTION}

The species Eugerres brasilianus (Cuvier, 1830) is found along all Brazilian coast, specially during the summer. Several aspects of its biology have been studied (Eiras \& Stofella, 1986; EirasStofella \& Fanta, 1991; Pérez-Hernándes \& Zavala-Hurtado, 1993). The branchial ultrastructural features of fishes has helped in the understanding of several physiological and behavioral aspects of different species (EirasStofella, 1994; Vandenberg et al, 1994; Minbattiwalla \& Gazdar, 1996; Dunel-Erb et al, 1997; Eiras-Stofella \& Charvet-Almeida, 1997, 1998; Fernandes et al, 1998; Galvez et al, 1998).The present study reveals the images obtained of the branchial surface of Eugerres brasilianus and they indicate some functional aspects.

\section{MATERIALS AND METHODS}

Eleven adult fishes (12.5-18.0cm) of Eugerres brasilianus were obtained from trawl nets in the beach of Pontal do Paraná, south coast of Brazil.
The fishes were identified according to Menezes \& Figueiredo (1980). The gills or branchial arches were submitted to the routine chemical, dehydration and gold coating treatment described in previous studies (Eiras-Stofella \& CharvetAlmeida, 1997, 1998). The electronmicrographs were obtained in a Philips SEM-505 scanning electron microscope.The ultrastructural description of the gills was done through the analysis of the second gill arches of the fishes (Hughes, 1984).

\section{RESULTS}

The gills presented a strong curvature angle on the superior third portion of the arch. The branchial filaments were slightly shorter on the extremities of the arch and in the region of the curvature angle. Both sides of the arch presented similar morphological characteristics in relation to the filaments and to the rakers observed in the pharyngeal region (Fig. 1). The branchial filaments include wide primary lamellae which became thinner towards the tip of the filament .The secondary lamellae presented a discrete

\footnotetext{
* Author for correspondence
} 
development (Fig. 2).The pharyngeal region showed pairs of rakers (Fig. 3). The rakers are short and formed by several saliences that contain many taste buds (Fig. 4 and 5). On the lateral sides of the arches there were groups of spines on the base of each raker and between the rakers a great quantity of taste buds was observed. The stratified epithelium of all gill was formed by cells with concentric microridges on their surface. The microridges were less abundant in the secondary or respiratory lamellae. Mucous cells were extremely common in the primary lamellae and in the gill pharyngeal region.

\section{DISCUSSION}

Comparison of the gill morphology of $E$. brasilianus with other tropical teleosts (EirasStofella, 1994) did not show any particular structural aspects. The abundance of mucous cells in the primary lamellae and in the pharyngeal region suggested that the production of this secretion provided greater protection to the small respiratory lamellae. Rakers which were not very prominent and the presence of several taste buds indicated that the food selection in this species was done through chemical receptors and not by the mechanical action of the branchial structures (Eiras-Stofella, 1994; Vanderberg et al, 1994; Eiras-Stofella \& Charvet-Almeida, 1997,1998). E. brasilianus is characterized by a highly protractile mouth (Pérez-Hernandez \& Zavala-Furtado, 1993) but it has an omnivorous feeding habit, ingesting mainly on small organisms (Vasconcelos Filho et al, 1981; Eiras-Stofella, 1994). The structures of the gill arches of this species are particularly specialized and suited for this feeding habit. The presence of sturdy but not very well developed rakers, groups of spines and the lack of other ultrastructural features capable of developing a plankton feeding habit reinforces that food selectivity.

\section{ACKNOWLEDGEMENTS}

We would like to thank Mrs. Vera Regina Fontana Pionteke (Electron Microscopy Center, Federal University of Paraná) for her help with the photographic work in this paper and the National Research Council of Brazil (CNPq) for the partial financial support given to this research project.

\section{RESUMO}

Peixes adultos da espécie Eugerres brasilianus (Gerreidae) tiveram suas brânquias analisadas em microscópio eletrônico de varredura. O epitélio de revestimento é uniforme em todas as porções dos arcos. É formado por células com micropregas concêntricas principalmente nas lamelas primárias e na região faríngea, locais onde são abundantes as células que secretam muco. A caracterização ultraestrutural das brânquias de E. brasilianus indica que a espécie não é filtradora e que em sua alimentação deve predominar a ingestão de pequenos organismos. Esses resultados estão de acordo com os dados da literatura que determinam o hábito alimentar da espécie através de análises de conteúdo estomacal e outros aspectos.

\section{REFERENCES}

Dunel-Erb, S.; Barradas, C. \& Lignon, J. (1997), Morphological evidence for the existence of two distinct types of mitochondria rich cells in the gill of the crayfish Astacus leptodactylus Eschscholtz. Act. Zool. Stockholm, 78(3):195-203

Eiras, D. R. de B. \& Stofella, R. R. (1986), Considerações sobre o efeito da salinidade no desenvolvimento de juvenis de Eugerres brasilianus (Cuvier, 1830) (Pisces-Gerreidae), em laboratório. Nerítica. Pontal do Paraná, 1(3): 1-7

Eiras-Stofella, D. R. (1994), Variabilidade morfológica da região faríngea dos arcos branquiais de algumas espécies de peixes (Teleostei), estudadas através da microscopia eletrônica de varredura. $\mathrm{PhD}$ Thesis, Universidade Federal do Paraná, Curitiba, Brazil

Eiras-Stofella, D. R. \& Charvet-Almeida, P. (1997), Gills of the freshwater fish Hypostomus commersonii Val., 1840 (Loricariidae) analysed through electron microscopy techniques. Arq. Biol. Tecnol. Curitiba. 40(4):785-792

Eiras-Stofella, D.R. \& Charvet-Almeida, P. (1998), Ultrastructure (SEM) of the gills of Prochilodus scrofa Steindachner, 1881 (Pisces, Teleostei). Revta. Bras. Zool. Curitiba, 15(2), 279-287

Eiras-Stofella, D. R. \& Fanta, E. (1991), Ontogenesis of Eugerres brasilianus (Cuvier, 1830) ( PiscesGerreidae) obtained by fertilization "in vitro". Rev. Biol. Mar. Valparaíso, 26(1): 21-36 
Fernandes, M.N. ; Perna, S.A. \& Moron, S.E. (1998), Chloride cell apical surface changes in gill epithelial of the armoured catfish Hypostomus plecostomus during exposure to distilled water. J.Fish.Biol. London, 52(4): 844-849

Galvez, F.; Webb, N.; Hogstrand, C. \& Wood, C.M.(1998), Zinc binding to the gills of rainbow trout: The effect of long-term exposure to sublethal zinc. J. Fish. Biol. London, 52 (6): 1089 - 1104

Hughes, G. M. (1984), General anatomy of the gills. In: Fish Physiology, ed. Hoar, W. S. \& Randall, D. J., Academic Press. Orlando. 1-72

Menezes, N.A. \& Figueiredo, J.L. (1980), Manual de peixes marinhos do sudoeste do Brasil. Teleostei. Museu de Zoologia, São Paulo. 4(3): 1-96

Minbattiwalla, M.B. \& Gazdar, G.S. (1996), Ultrastructure of the chloride cells in gills of black mollies (Pisces: Poecilidae). J.Anim. Morph. Physiol. Baroda, 43(1): 45-49

Pérez-Hernándes, M.A. \& Zavala-Hurtado, J.A. (1993), Biometry of the Eugerres plumieri-Eugerres brasilianus (Pisces - Gerreidae) complex from the
Gulf of México. A mutivariate approach. Rev. Biol. Trop. San Jose. 41(1): 121-130

Vandenberg, C.; Vanderboogaart, J. G. M.; Sibing, F. A. \& Osse, J. W. M. (1994), Implications of gill arch movements for filter-feeding. An x-ray cinematographical study of filter-feeding white bream (Blicca bjoerkna) and common bream (Abramis brama). J. Exp. Biol. Cambridge. 191: 257-282

Vasconcelos Filho, A. de L.; Souza Jr., A. E. \& Alves, M. L. C. (1981), Estudo ecológico da região de Itamaracá-Pernambuco-Brasil, XVII: Alimentação das carapebas Diapterus olisthostomus Good \& Bean, 1882 e Eugerres brasilianus Cuv. \& Val., 1830 (Pisces-Gerreidae), em viveiros estuarinos. Paper presented at Congresso Brasileiro de Engenharia da Pesca, Recife, Pernambuco. Anais: 285-296

Received: September 10, 1999 Revised: October 21, 1999, Accepted: December 07, 1999. 